\title{
Implementasi Program Badan Usaha Milik Desa (BUMDes) Di Desa Polohungo Kecamatan Dulupi Kabupaten Boalemo
}

\author{
Noval Adriyanus Karim 1), Rosman Ilato ${ }^{2)}$, Raflin Hinelo ${ }^{3)}$ \\ ${ }^{1)}$ Mahasiswa Jurusan Pendidikan Ekonomi, Universitas Negeri Gorontalo \\ 2)Dosen Jurusan Administrasi Publik, Universitas Negeri Gorontalo \\ ${ }^{3}$ Dosen Jurusan Manajemen, Universitas Negeri Gorontalo \\ adrianuskarimn@gmail.com
}

\begin{abstract}
The research objective is to understand the determinant factor of Village-Owned Enterprises (BUMDes) Program in Polohungo Village. Dulupi Sub-district. Boalemo District. Method applied in this research is qualitative, while the analysis uses interview analysis.

The research finding concludes that in general, the implementation of VillageOwned Enterprises (BUMDes) Program in Polohungo Village is well-performad as main program in the BUMDes like kopiah karanji (men's typical cap made of rattan or dried water hyacinth) craft and the brick production show continuity. However the program has not run optimally as several matters require attention and improvement.
\end{abstract}

Keywords: Implementation, BUMDes Program.

\section{PENDAHULUAN}

Kemandirian suatu daerah merupakan tuntutan dari pemerintah pusat saat diberlakukannya otonomi pada masa orde baru yaitu pada tahun 1966 M. Era otonomi ini membuat daerah-daerah yang ada di Indonesia berlomba-Iomba untuk menjadi daerah yang terbaik diantara daerah-daerah lainnya karena ini menjadi peluang besar bagi daerah untuk memajukan dan mengembangkan daerahnya sendiri untuk mencapai kesejahteraan bagi masyarakat dan pegawainya. Demi tercapainya wacana daerah untuk memajukan dan mengembangkan daerahnya, maka daerah harus mengatur strategi dalam menjalankan pemerintahannya untuk dapat dimaksimalkan guna mendukung peningkatan kehidupan 
lebih yang baik, baik itu dalam bidang ekonomi, sosial maupun politik.

Era otonomi saat ini, bukan hanya daerah yang memiliki otonomi daerah akan tetapi desa juga memiliki otonomi desa yang mana desa memiliki hak dan kewenangan penuh dalam mengelola dan menjalankan pemerintahannya sendiri sehingga mandiri dan kreatif dalam meningkatkan kemajuan dan kesejahteraan masyarakat yang ada di desa yang pertama kali diatur dalam Undang-undang No. 8 Tahun 2005 tentang perubahan atas Undang-undang No. 32 Tahun 2004 tentang Pemerintahan Daerah. Seiring berjalannya waktu, undangundang tersebut mengalami perubahan menyesuaikan keadaan yang terjadi, hingga pemerintah memiliki inisiatif untuk desa dianggap sebagai tempat yang udik dan rendahan di banding kelurahan, sehingga tidak sedikit desa yang beralih menjadi kelurahan untuk mengangkat derajat sosial di mata masyarakat lainnya. Hal ini tentu tidak bisa membuat pemerintah berdiam diri, karena jika dibiarkan maka desa akan perlahan hilang, sedangkan desa sangat penting untuk kelestarian adat dan budaya. Maka dari itu, pemerintah pusat ingin mendongkrak mindset ini dengan dikeluarkannya Undangundang No. 6 Tahun 2014 tentang Desa yang terbaru yang mana desa merupakan daerah otonom dan berhak untuk mengatur dan mengeluarkan undang-undang tentang Desa.

Selama mengelola desanya sendiri. Sebagai daerah yang memiliki otonomi penuh, untuk menjalankan pemerintahannya, maka desa harus mencari dana sendiri untuk mengembangkan desanya. Meski sekarang dalam Undangundang No. 6 Tahun 2014 menyatakan bahwa desa akan mendapatkan bantuan dari APBN setiap tahunnya sekitar 600 juta hingga 1,2 Milyar yang tercantum daIam UU No. 6 Tahun 2014 pasaI 72 ayat (1) dan ayat (4) tentang desa, akan tetapi desa tidak sepenuhnya menggantungkan pendapatannya dari bantuan tersebut.

Karena sebelum Undang-undang diberlakukan bantuan alokasi dana desa yang tidak ada, maka desa harus menguras tenaga dan mencari jalan keluar untuk mendapatkan pendapatan Desa yang maksimal. Maka dari itu desa harus menggali potensi desa baik dari segi Sumber Daya Alam (SDA) maupun dari segi Sumber Daya Manusia (SDM) yang ada di desa tersebut yang nantinya akan menjadi sumber pendapatan desa dan akan masuk kedalam kas desa atau keuangan desa.

Keuangan desa yang didapatkan dari sumber pendapatan desa haruslah dikelola dengan baik demi 
tercapainya pembangunan desa. Namun, kita ketahui bahwa sumber pendapatan desa sebagian besar berasal dari bantuan pemerintah pusat maupun pe-merintah daerah, karena memang desa merupakan daerah otonom yang kecil sehingga jika hanya mengandalkan pendapatan asli desa tidak akan mampu meningkatkan pembangunan desa baik itu meningkatkan dalam segi infrastruktur maupun dalam segi administratif. Sehingga perlu pengelolaan dan manajemen yang baik dalam pendapatan asli desa dan keuangan desa agar desa memiliki pendapatan yang memadai untuk menopang kesejahtearaan masyarakat desa.

Salah satu strategi dalam memudahkan desa untuk mendapatkan sumber pendapatan desa adalah pemerintah membuat kebijakan yang mengatur hal tersebut. Salah satunya adalah undangundang No. 32 Tahun 2004 tentang pemerintah daerah yang meyebutkan bahwa pemerintah desa juga dianjurkan untuk memiliki Badan Usaha Milik Desa (BUMDes) yang berguna untuk mengatur perekonomian desa dan memenuhi kebutuhan serta menggali potensi desa, dan Undang-undang ini merupakan salah satu upaya dari pemerintah pusat dalam meningkatkan peran desa untuk ikut dalam meningkatkan perekonomian desa.
Undang-undang tersebut selaras dengan Peraturan Menteri Dalam Negeri No. 39 Tahun 2010 tentang Badan Usaha Milik Desa yang merupakan peraturan lanjutan dari UU No. 32 Tahun 2004 dimana dalam peraturan ini disebutkan bagaimana cara mendirikan dan mengelola BUMDes itu sendiri.

BUMDes merupakan salah satu lembaga yang terdapat interaksi ekonomi antara pemerintah desa dengan masyarakat desa, sehingga hal ini juga berdampak pada hubungan antara pemerintah desa dengan masyarakat yang akan tercipta secara alamiah. Adanya BUMDes ini akan menarik masyarakat untuk memulai berdagang sehingga secara perlahan angka kemiskinan akan menurun dan mengangkat keluarga yang tidak mampu untuk menjadi keluarga yang sejahtera.

BUMDes sendiri memiliki literatur yang sama dengan BUMN (Badan Usaha Milik Negara) dan BUMD (Badan Usaha Milik Daerah) yaitu sama-sama mengelola aset dibidangnya hanya saja BUMN merupakan badan usaha tingkat nasional yang dimiliki oleh negara dan BUMD tentu saja merupakan badan usaha milik daerah yang mengelola aset-aset yang ada didaerah, hanya saja BUMDes ini ruang lingkupnya masih sederhana tidak seperti BUMN yang Nasional 
dan BUMD yang ruang lingkupnya sekitar provinsi, kabupaten/kota. Maka BUMDes yang berada di Desa Polohungo juga memiliki fungsi yang sama, yaitu mengelola seluruh aset yang dimiliki desa baik itu fisik maupun non fisik yang sifatnya kearah perekonomian desa.

Desa Polohungo ini merupakan desa yang ada di tengah-tengah kota yang berada di wilayah Kabupaten Boalemo. Desa Polohungo ini menjadi titik perlintasan antara kabupaten/kota. Posisi yang strategis yang berada dilintasan jalan kecamatan antara kecamatan Paguyaman dan kecamatan Tilamuta ini membuat masyarakat umum melewati jalan desa Polohungo yang hendak menuju pusat kota kabupaten, dan kota provinsi. Sehingga pemerintah desa memiliki keinginan agar bagaimana caranya Desa Polohungo ini bukan hanya menjadi daerah lintasan semata akan tetapi menjadi daerah singgahan orang-orang yang melintas di Desa Polohungo ini. Maka dari itu Pemerintah Desa berinisiatif untuk membangun BUMDes (Badan Usaha Milik Desa) untuk menjadi motor penggerak ekonomi di Desa Polohungo dan diharapkan bisa mengeksplor kopiah karanji Desa Polohungo.

Program-program BUMDes Polohungo ini memang tidaklah banyak, meski hanya memiliki 2 (dua) program utama yaitu kerajinan kopiah karanji dan produksi batako tapi bisa berjalan lancar meski banyak sekali hambatan dilapangan. Kedua program BUMDes ialah sebagai berikut.

Pelaksanaan Badan Usaha Milik Desa (BUMDes) di Desa Polohungo ini bukan tanpa hambatan. Masih terdapat beberapa masalah dalam pelaksanaannya. Setelah peneliti melakukan observasi awal mengenai Implementasi Program Badan Usaha Milik Desa dan berdasarkan wawancara awal peneliti dengan beberapa pihak terkait, maka terdapat beberapa masalah, yaitu sebagai berikut.

Pertama, kurangnya pem-binaan dan bimbingan dari pemerintah daerah juga dukungan berupa bantuan dana financial maupun non financial. Hal ini disebabkan karena Pemerintah Daerah Kabupaten Boalemo belum mengadakan program khusus untuk pengenalan dan pengembangan BUMDes ke Pemerintah Desa, seperti bimbingan teknis mengenai BUMDes, pembinaan terhadap pengurus BUMDes, dan pelatihan pengelolaan keuangan BUMDes. Dengan pembinaan dan bimbingan tersebut diharapkan agar BUMDes di Desa Polohungo ini semakin berkembang.

Selain itu, mayoritas masyarakat desa adalah masyarakat tradisional yang masih awam tentang ekonomi 
dan usaha. Yang mereka tahu hanyalah bagaimana cara mereka makan hari ini. Cara pandang ini tentu saja harus diubah diiringi zaman yang semakin modern dan canggih. Perlu diadakan sosialisasi agar masyarakat bisa berpartisipatif dan berkontribusi dengan baik dalam program-program BUMDes. Kurang partisipatifnya masyarakat bisa juga dikarenakan dalam mendirikan BUMDes sendiri dengan cara top down yang mana BUMDes ini dibentuk dikarenakan adanya inisiatif dari Pemerintah Desa Polohungo untuk menghimpun suatu wadah untuk menampung programprogram pemerintah yang bersifat pemberdayaan masyarakat miskin, bukan karena inisiatif dari masyarakat sendiri. Karena jika BUMDes ini didirikan berdasarkan kemauan masyarakat dan didukung dengan pemerintah desa maka pemerintah desa bisa dengan mudah menjalankan BUMDes ini karena partisipasi dari masyarakat tentulah akan tinggi dan ini berbeda jika BUMDes ini dibentuk atas dasar kemauan sekelompok kecil saja atau pemerintah desa.

Meski ruang lingkup BUMDes ini masih minim hanya sekitaran desa saja, namun pihak pengelola BUMDes ini menginginkan Desa Polohungo ini menjadi daerah singgahan dengan kerajinan kopiah karanji khas gorontalo bagi masyarakat pendatang jauh diluar dari Desa Polohungo. Namun harapan mereka hanya sebatas wacana jika tanpa adanya promosi dan iklan karena keterbatasan teknologi yang mereka miliki. Jika berkaca pada pengusaha swasta disekitar mereka yang difasilitasi dengan kecanggihan teknologi mereka jauh tertinggal beberapa tingkat jika dibandingkan.

Beberapa hal yang ditemukan saat observasi awal tersebut di atas mengindikasikan bahwa masih adanya masalah dalam pelaksanaan program BUMDes di Desa Polohungo Kabupaten Boalemo. Oleh karena itu, peneliti tertarik untuk melakukan penelitian dengan judul "Implementasi Program Badan Usaha Milik Desa (BUMDes) di Desa Polohungo Kecamatan Dulupi Kabupaten Boalemo.

\section{Tujuan PeIaksanaan}

Faktor determinan implementasi (BUMDes) di Desa Polohungo.

\section{Manfaat Penelitian}

Manfaat yang diharapkan dari penelitian ini Sebagai bahan untuk memperluas wawasan dan memberikan pengetahuan yang lebih tentang Ilmu Administrasi Negara khususnya yang berkaitan dengan implementasi Program Badan Usaha Milik Desa (BUMDes) di Desa Polohungo Kecamatan Dulupi 
Kabupaten Boalemo.

a. Bagi peneliti

Manambah ilmu pengetahuan khususnya Ilmu Adminstrasi Negara yang berkaitan tentang masalah dalam implementasi Program Badan Usaha Milik Desa (BUMDes) di Desa Polohungo Kecamatan Dulupi Kabupaten Boalemo.

b. Bagi pemerintah

Pihak Pemerintah Daerah Kabupaten Boalemo dan Pemerintah Desa Polohungo ialah mengetahui implementasi Program Badan Usaha Milik Desa (BUMDes) di Desa Polohungo Kecamatan Dulupi Kabupaten Boalemo.

c. Bagi masyarakat

Manfaat bagi masyarakat dan dunia usaha adalah membangun kesadaran masyarakat dan dunia usaha untuk peduli dalam mengelola BUMDes di Desa Polohungo ini sehingga bisa terus berkembang dan maju dalam mengatasi kemiskinan dan keluar dari desa tertinggal.

\section{KAJIAN PUSTAKA}

\section{Pengertian Badan Usaha Milik Desa} (BUMDES)

Organisasi perekonomian pedesaan merupakan bagian penting sekaligus menjadi titik lemah pendukung penguatan perekonomian pedesaan. Oleh karena itu, perlu diupayakan sistematika untuk mendorong organisasi ini supaya mampu mengelola aset ekonomi strategis desa. Tujuannya adalah mengembangkan jaringan ekonomi dan meningkatkan daya saing ekonomi pedesaan. Dengan demikian diperlukan usaha dan kiatkiat strategis dan tepat untuk mencapai tujuan tersebut. Kiat pertama yang dilakukan adalah membentuk wadah pengembangan jaringan ekonomi dalam hal ini adalah pembentukan BUMDES. Diterbitkannya Undang-Undang Nomor 8 Tahun 2005 tentang Perubahan atas Undang-Undang Nomor 32 Tahun 2004 tentang Pemerintah Daerah, sebagaimana diamanatkan dalam Bab VII bagian kelima yang menyatakan Pemerintah Desa dapat mendirikan Badan Usaha Milik Desa sesuai dengan kebutuhan dan potensi desa dengan harapan dapat meningkatkan pendapatan masyarakat dan desa. Sebagai tindak lanjut dari pelaksanaan pendirian BUMDes, maka berdasarkan PasaI 78 PP 72 Tahun 2005 Tentang Desa, dijelaskan bahwa Pemerintah Kabupaten-Kota perlu menetapkan Peraturan Daerah tentang Badan Usaha Milik Desa. Selanjutnya dijelaskan dalam Permendagri No. 39 tahun 2010 bahwa bahwa untuk meningkatkan kemampuan keuangan pemerintah desa dalam penyelenggaraan pemerintahan

Meningkatkan pendapatan masyarakat melalui berbagai kegiatan usaha ekonomi masyarakat pedesaan, 
didirikan badan usaha milik desa sesuai dengan kebutuhan dan potensi desa. Dalam konteks ini, BUMDes pada dasarnya merupakan bentuk konsolidasi atau penguatan terhadap lembaga-lembaga ekonomi desa. BUMDes juga merupakan instrumen pendayagunaan dan pemberdayaan ekonomi lokal dengan berbagai ragam jenis potensi. Pendayagunaan dan pemberdayaan potensi bertujuan meningkatkan kesejahteran ekonomi warga desa melalui pengembangan usaha ekonomi mereka. Disamping itu, keberadaan BUMDes juga memberikan sumbangan bagi peningkatan sumber pendapatan asli desa yang memungkinkan desa mampu melaksanakan pembangunan dan peningkatan kesejahteraan rakyat secara optimal. Dalam rangka membangkitkan ekonomi pedesaan Pemerintah Kabupaten Tabanan Bali, perlu dikembangakan Usaha

Pengembangan Ekonomi Kerakyatan Mandiri (UP-EKM). Tujuannya adalah menggali potensi ekonomi pedesaan dengan menggali dan memberdayakan potensi yang dimiliki desa. Beberapa hal yang dapat dilakukan adalah: (i) pengembangan kemampuan SDM sehingga Jurnal Bakti Saraswati Vol. 05 No. 02. September 2016 ISSN : 2088-2149 196 mampu memberikan nilai tambah dalam pengelolaan aset ekonomi desa, (ii) mengintegrasikan produk-produk ekonomi perdesaan sehingga memiliki posisi nilai tawar baik daIam jaringan pasar, (iii) mewujudkan skala ekonomi kompetitif terhadap usaha ekonomi yang dikembangkan, (iv) menguatkan kelembagaan ekonomi desa, (v) mengembangkan unsur pendukung seperti perkreditan mikro, informasi pasar, dukungan teknologi dan manajemen, prasarana ekonomi dan jaringan komunikasi maupun dukungan pembinaan dan regulasi.

\section{METODOLOGI PENELITIAN}

Penelitian ini menggunakan pendekatan kualitatif. Penelitian kualitatif adalah penelitian tentang riset yang bersifar deskriptif dan cenderung menggunakan analisis. Proses dan makna (perspektif subjek) lebih ditonjolkan dalam penelitian kualitatif. Landasan teori dimanfaatkan sebagai pemandu agar fokus penelitian sesuai dengan fakta di lapangan. Selain itu landasan teori ini juga bermanfaat untuk memberikan gambaran umum tentang latar penelitian dan sebagai bahan pembahasan hasil penelitian. Terdapat perbedaan mendasar antara peran landasan teori dalam penelitain kuantitatif dan kualitatif. Dalam penelitian kualitatif, penelitian berangkat dari teori menuju data, dan berakhir pada penerimaan atau penolakan terhadap teori yang digunakan; sedangkan penelitian kualitatif peneliti bertolak dari data, 
manfaat teori yang ada sebagai bahan penjelas, dan berakhir dengan suatu "teori"

\section{Sumber Data}

\section{a) Sumber Data Primer}

Data penelitian ini dapat diperoleh melalui wawancara dengan informan yang masing-masing adalah kepala desa, pengelola BUMDes, dan unsur lain yaitu masyarakat sesuai dengan kebutuhan penelitian.

b) Sumber Data Sekunder

Data sekunder dapat berupa dokumen, laporan, data statistik, dan data lainnya yang berhubungan dengan fokus penelitian.

\section{Analisis Data}

Analisis data dalam penelitian akan diolah secara kualitatif menurut Creswell (2015:468) yaitu;

a. Mengkoordinasikan data

Penglolaan data awal terdiri atas mengorganisasikan data, mentranskripsikan wawancara dan mengetikan catatan lapangan, dan mengambil keputusan untuk menganalisis datanya dengan tangan atau computer.

b. Mengeksplorasikan data

Melaksanakan analisis pendahuluan terhadap data dengan membacanya secara seksama untuk mendapatkan perasaan dengan membacanya secara seksama untuk mendapatkan perasaan umum tentang data.
Proses pengodean adalah mereduksi basis data teks atau gambar menjadi deskripsi, atau tentang tema, orang, tempat, atau kejadian.

c. Merepresentasikan

Merepresentasikan temuan peneliti dalam tampilan visual yang mungkin termasuk gambar, diagram, tabel, perbandingan, dan tabel demografis.

d. Menginterpretasi

Membuat interpretasi tentang makna penelitian, membuat pembanding antara temuan dan kepustakaan, dan menyebutkan keterbatasan serta menyarankan peneliti dimasa mendatang.

e. Mendeskripsikan data

Menjawab pertanyaan penelitian utama dan membentuk pemahaman tentang fenomena sentral melalui deskripsi.

f. Memvalidasi keakuratan

Menerapkan prosedur validasi untuk meminta data yang rill sesuai fakta.

\section{HASIL PENELITIAN}

Program BUMDes sendiri memang sudah di anjurkan pada tahun 2007 oleh kementrian dalam negeri saat itu yang tertuang dalam Permendagri No. 37 tahun 2007 tentang Pedoman Pengelolaan Keuangan Desa. Namun pada saat itu masih dalam tahap penyesuaian, sehingga turunlah Permendagri No. 39 tahun 2010 tentang BUMDes. 
Dalam Permandgari 39/2010 ini memuat khusus bagaimana mekanisme BUMDes dibuat dan pengelolaannya. Hal ini juga disebutkan juga oIeh salah satu informan sebagai berikut.

“Program ini mulai berjalan pada di saat Permendagri No. 37 Tahun 2007 Tentang Pedoman Pengelolaan Keuangan Desa dibuat, itu sudah berapa kali perubahan, yang terakhir dipertegas dengan Permendagri No. 39 Tahun 2010 Tentang Badan Usaha Milik Desa, dimana didalamnya menyebutkan bahwa BUMDes didirikan sebagai motor penggerak perekonomian desa." (Wawancara dengan Pak S, 2 Agustus 2019, PukuI 10.40 WITA)

Namun, di kabupaten Boalemo sendiri baru dikenal pada tahun 2013, seperti halnya yang disampaikan oleh ISM Desa Polohungo sebagai berikut. “Dikabupaten sendiri boomingnya itu pada tahun 2013, tapi memang sebelum itu juga sudah ada kebijakan yang mengatur tentang BUMDes itu, tapi boomingnya itu pada tahun 2013, karena memang itu lumbungnya desa yang dibentuk oleh desa sendiri dan juga didukung dan ditopang oleh masyarakat." (Wawancara dengan Pak NK, 3 Agustus 2019)

Berdasarkan wawancara diatas bisa dilihat bahwa pada tahun 2013 BUMDes baru dikenal oleh desa, karena memang pada saat permendagri 39/2010 dibuat pemerintah Kabupaten Boalemo tidak langsung membuat turunannya atau Perdanya. Perdanya sendiri baru dibuat pada tahun 2014, sedangkan dalam Permendagri 39/2010 sendiri menyebutkan dalam pasal 3 ayat (2) yang berbunyi "Peraturan Daerah Kabupaten/Kota sebagaimana dimaksud pada ayat (1) ditetapkan paling lambat 1 (satu) tahun sejak Peraturan Menteri ini ditetapkan". Jika Permendagri 39/2010 ditetapkan tahun 2010, maka tahun 2011 daerah harus membuat perda tersebut. Akan tetapi nyatanya Pemerintah Kabupaten Boalemo sendiri baru membuat tahun 2014, Sehingga desa-desa di Kabupaten Boalemo bisa dibilang tertinggal dalam membuat BUMDes. Di Desa Polohungo sendiri dibuat pada tahun 2013, satu tahun sebelumnya dibuatnya Perbup tentang BUMDes. Dan pada saat Perbup dibuat pada tahun 2014, maka Desa Polohungo harus menyesuaikan kembali dengan Pergub yang berlaku, seperti yang dinyatakan oleh Kasubag Dokumentasi Hukum Bagian Hukum Sekretariat Kabupaten Boalemo sebagai berikut.

"Peraturan desa tidak akan berlaku jika ada peraturan yang lebih tinggi, peraturan desa harus mengacu pada pergub ini. Jadi desa harus merevisi ulang perdesnya disesuaikan dengan perbup yang berlaku 
yaitu Perbup No. 85 Tahun 2014 yang merupakan turunan dari Perda No. 9 Tahun 2014 tentang Desa." (Wawancara dengan Pak Agus Hendrik, 3 Agustus 2019)

Berdasarkan wawancara diatas bisa dilihat bahwa desa memang harus merevisi ulang, dan pada saat di konfirmasi kepada Sekretaris Desa Polohungo, memang perdes tersebut akan direvisi sekaligus penyegaran pengurus seperti yang disampaikannya sebagai berikut.

"Rencana sih ada, kita juga akan menyesuaikan dengan keadaan desa sekarang ini, disisi lain kita juga akan mengadakan rolling pengurus ya karena mungkin ada beberapa yang sibuk, supaya lebih instan lagi, untuk penyegaranlah. Kadang-kadang kan ada jenuh juga ya, karena tadi juga ada permen dan perbup yang mengatur."

(Wawancara dengan Rahmat Radji, 10 Agustus 2019, PukuI 10.10 WITA, di Kantor Desa Polohungo). Berdasarkan wawancara diatas bisa dilihat bahwa desa memang harus merevisi ulang, dan pada saat di konfirmasi kepada Sekretaris Desa Polohungo, memang perdes tersebut akan direvisi sekaligus penyegaran pengurus seperti yang disampaikannya sebagai berikut "Rencana sih ada, kita juga akan menyesuaikan dengan keadaan desa sekarang ini, disisi lain kita juga akan mengadakan rolling pengurus ya karena mungkin ada beberapa yang sibuk, supaya lebih instan lagi, untuk penyegaran lah. Kadang- kadang kan ada jenuh juga ya, karena tadi juga ada permen dan perbup yang mengatur."

(Wawancara dengan Rahmat Radji, 10 Agustus 2019, Pukul 10.10 WITA, di Kantor Desa Polohungo) Namun disisi lain, IPM Desa Polohungo beranggapan bahwa Perbup hanya sebatas aturan yang menyeragamkan saja, artinya tidak terlalu berpengaruh pada perdes, nyatanya banyak desa yang sudah memiliki BUMDes sebelum Perbup tentang BUMDes dibuat pada tahun 2014. Hal ini dinyatakan daIam wawancara sebagai berikut.

"Menurut saya, Perbup ini hanya mengatur saja yang merupakan turunan dari undang-undang atau perda tentang tata kelolanya saja. Memang saya akui sebelum dibuatnya Perbup ini, sebagian desa sudah memiliki BUMDes dan memang harus ada perdesnya saat dibuatnya BUMDes ini. Nah, pada saat 2014 dibentuknya perbup ini baru diwajibkan untuk seluruh desa yang ada di Kabupaten Boalemo." (Wawancara dengan Pak Meldi Tahir 3 Agustust 2019).

Berdasarkan hasil wawancara diatas bisa dilihat bahwa BUMDes memang perlu dibentuk, sehingga saat ada anjuran dari pemerintah pusat Desa Polohungo memiliki inisiatif membentuk BUMDes meski 
pemerintah daerah sendiri belum memiliki payung hukum dalam pembentukkan BUMDes saat BUMDes akan dibentuk pada tahun 2013 itu, menunjukkan bahwa payung hukum yang dibuat pemerintah daerah terlambat dibuat karena mengacu pada UU No. 6 Tahun 2014 tentang desa sedangkan Peraturan Desa mengacu pada Permendagri No. 39 Tahun 2010. Sehingga Peraturan desa akan direvisi ulang menyesuaikan peraturan daerah No. 9 Tahun 2014 dan Perbup No. 85 Tahun 2014. Tujuan Perbup ini dibuat hanya untuk menyeragamkan desa dalam membentuk BUMDes agar tidak berbeda- beda dasar hukum yang dipakai.

\section{PENUTUP}

\section{Simpulan}

Implementasi program BUMDes di Desa Polohungo secara umum sudah berjalan dengan baik. Hal ini dapat dilihat berdasarkan dari berjalannya program-program utama BUMDes secara baik. Akan tetapi ada beberapa hal yang harus lebih diperhatikan dan diperbaiki. Berdasarkan Peraturan Desa No. 7 Tahun 2013188 tentang Pengelolaan dan Pelaksanaan BUMDes yaitu, Meningkatkan perekonomian Desa Polohungo, meningkatkan pendapatan asli Desa Polohungo,
Meningkatkan pengolahan potensi desa sesuai dengan kebutuhan masyarakat Desa Polohunggo dan menjadi program unggulan dalam meningkatkan pertumbuhan dan pemerataan ekonomi Desa Polohunggo.

\section{Saran}

1) Sebagai desa yang berada di tengah kota, desa harus bisa memanfaatkan hal ini untuk bisa melakukan Kerjasama dengan para pengembang agar mendapatkan bantuan atau tambahan dana untuk pengembangan program-program BUMDes.

2) Meningkatkan pengelolaan BUMDes, memperkuat pola komunikasi antara Lembaga Desa.

3) Melakukan sosialidasi lebih intensif lagi agar masyarakat desa bisa mengetahui program BUMDes yang di laksanakan Desa sehingga tidak ada kesalahfahaman antara masyarakat dan pemerintah desa. Selain itu perlu diadakan sosialisasi kepada desadesa yang ada di Kabupaten Boalemo, agar desa yang belum mengerti program-program BUMDes tertarik untuk mendirikan BUMDes di desanya. 


\section{DAFTAR PUSTAKA}

Ariani dan Yusuf Idris. 2009. Metode Pembelajaran Ekonomi. Makalah Disajikan pada Pendidikan dan Pelatihan Guru Ekonomi Jenjang Dasar. PPPPTK PKn dan IPS Malang, 4 s/d 15 Desember 2009.

Arends, Richard. I. 2008. Learning to teach. Yokyakarta: Pustaka Pelajar.

Asri Budiningsi. 2012. Belajar dan Pembelajaran. Jakarta : Rineka cipta

Departemen Pendidikan Nasional Universitas Negeri Gorontalo. 2009. Buku Pedoman Penulisan Karya Ilmiah. Gorontalo: UNG.

Dimyati dan Mudjiono. 2006.

Belajar dan Pembelajaran.

Cetakan Ketiga. Jakarta: Rineka Cipta.

Hamalik, Oemar. 2006. Proses Belajar Mengajar

Heri Rahyubi.2012. Teori-Teori

Belajar dan Aplikasi Pembelajaran Motorik Deskripsi dan Tinjauwan Kritis. Jakarta : Nusa media.

Ibrahim, Muslimin, dkk. 2000.

Pembelajaran Kooperatif. Surabaya : University Press.

Isjoni. 2011. Pembelajaran Kooperatif Meningkatkan Kecerdasan Komunikasi Antar Peserta Didik. Yogyakarta: Pustaka Pelajar.
Slavin, $\quad$ Robert. $\quad$ E. 2008. Cooperative Learning. Bandung: Nusa Media.

Suprijono, Agus. 2009. Cooperative Learning. Yogyakarta: Pustaka Pelajar.

Isjoni. 2011. Pembelajaran Kooperatif Meningkatkan Kecerdasan Komunikasi Antar Peserta Didik. Yogyakarta: Pustaka Pelajar. Sagala, Syaiful. 2009. Konsep dan

Makna Pembelajaran Untuk Membantu Memecahkan

Problematika Belajar dan Mengajar. Bandung: Alfabeta.

Suparlan. 2009. Penelitian Tindakan Kelas.

Makalah Disajikan pada

Pendidikan dan Pelatihan Guru Ekonomi Jenjang Dasar. PPPPTK PKn dan IPS Malang, 4 s/d 15

Desember 2009.

Suprijono, Agus. 2011. Cooperative

Learning Teori dan Aplikasi Paikem. Yogyakarta: Pustaka Pelajar.

Trianto. 2007. Model-model

Pembelajaran Inovatif Berorientasi Konstruktivistik Konsep, Landasan Teoritik.

Wijaya,Yoga Permana. 2010. Pengertian Belajar. Artikel Pengertian Belajar. (Online). (http://yogapw.wordpress.com/2 010/10/01/pengertia-belajar-2/, diakses 16 Juni 2019 